\title{
Analysis of E-Complaint Management in Glamping Businesses within the Scope of a Case Study
}

\author{
F. Kübra AYLAN iD a Güney ÇETIN GÜRKAN iD b \\ a Selçuk Üniversitesi, Turizm Fakültesi, Rekreasyon Yönetimi Bölümü, Konya, Türkiye, kubraceliloglu@selcuk.edu.tr \\ b Trakya Üniversitesi, Uygulamalı Bilimler Fakültesi, Turizm İşletmeciliği Bölümü, Edirne, Türkiye, guneycg@yahoo.com.tr
}

\begin{tabular}{l} 
ARTICLE INFO \\
\hline Keywords: \\
Glamping \\
E-Complaint \\
E-Complaint Management
\end{tabular}

Received 9 October 2021 Revised 10 December 2021 Accepted 20 December 2021

Article Classification: Research Article

\section{ABSTRACT}

Purpose - The purpose of the study is to create a foresight about what kind of method is followed by glamping businesses in e-complaint management and to develop various recommendations along with the results obtained.

Design / Methodology/ Approach - "Case study" was chosen as the qualitative research design of the study and the research data were collected with multiple data sources through document review, participant observation and unstructured interview. The data obtained by in-depth, unstructured, faceto-face interview method with the owner/manager of the glamping business on the management of complaints within the scope of the research and 115 comments for the glamping business in the Google Maps application between November 2020 and April 2021 were subjected to content analysis. The obtained data was analyzed by using the previously licensed MAXQDA@ 2018 package program.

Results - The data analyzed in the research were evaluated under two categories: "e-complaint" and "ecomplaint management". There are 5 themes under the e-complaint category and 11 themes under the e-complaint management category. The research results have shown that the business responded to positive posts more than negative posts. The business often stated in their responses to the complaints that they were trying to improve themselves, they thanked the guests for their constructive feedback and sharing their experiences and they were sorry for the bad experience. Some complaints were responded only with general statements without any explanatory information, while other complaints were explained not to be true.

Discussion - In line with the results of this research, recommendations were made to the glamping business and future academic studies on this subject.

\section{INTRODUCTION}

Glamping can be considered an innovative vacation experience (Ali and Amin, 2014). Glamping experiences are designed to combine being in touch with nature with high-quality accommodation (Lee et al., 2019) and they are also expressed as an open-air hotel experience (Union Lido, 2012). Glamping businesses combine accommodation, other hotel services and facilities with nature-based experiences. In these facilities, customers want to escape from the hustle and bustle of city life and immerse themselves in nature (Filipe et al., 2018). They have convenient indoor facilities and recreation facilities similar to traditional holiday resorts, but differ in the unique nature-based experiences they can offer their customers (Ali and Amin, 2014). It can be also said that the glamping industry, as a growing niche market, has great economic importance. For example, according to the study by Grand View Research, the global glamping market is expected to become a major market of $\$ 1.88$ billion in 2020 and reach $\$ 2.35$ billion by 2021. It is also anticipated that this market will reach a $\$ 5.41$ billion turnover from 2021 to 2028 (Grand View Research, 2021).

It can be mentioned that there are a limited number of studies in both foreign and Turkish literature on glamping, which is a relatively new concept. Looking at some of these studies, they include the case studies based on certain glamping businesses (Birdir et al., 2015; Düzgün, 2021), which examine glampers' motivations (Sakacova, 2013), the conceptual framework of glamping (Brooker and Joppe, 2013; Ergüven et al., 2015), customers' experiences (Brochado, 2019), rural development (Çelik et al., 2017), analysis of glamping businesses' web pages (Konak and Özhasar, 2019), the perceptions (Aksöz et al., 2020), experiences and perceived service quality of individuals participating in the camp and glamping (Brochado and Pereira, 2017; Vrtodušić Hrgovi'c et al., 2019) and the motivations of the glamping participants (Filipe et al., 2018) and also

\section{Suggested Citation}

Aylan, F.K., Çetin Gürkan, G. (2021). Analysis of E-Complaint Management in Glamping Businesses within the Scope of a Case Study, Journal of Business Research-Turk, 13 (4), 3525-3543. 


\section{F. K. Aylan - G. Çetin Gürkan 13/4 (2021) 3525-3543}

subject the views of glamping participants to content analysis (Brochado, 2019; Brochado and Brochado, 2019), and the studies examining areas with the potential for glamping (Göktas et al., 2017). As can be seen, it has been determined that the e-complaint management process of glamping businesses was not been investigated. When the previous studies are analyzed, it has been argued that any business should pay attention to ecomplaints and intervene immediately in guests' problems (Davidow, 2000; Mattila and Mount 2003; Lee and $\mathrm{Hu}, 2004)$. Thus, it will be possible for businesses to turn e-complaints into opportunities (Alrawadieh and Şehnaz Demirkol, 2015) by establishing an effective e-complaint management system. Accordingly, the study aims to create a foresight about what kind of method is followed by glamping businesses, which have recently seen a widespread increase in accommodation tendency in Turkey, in e-complaint management and to develop various recommendations along with the results obtained. "Case study" was chosen as the qualitative research design of the study and an in-depth investigation was carried out by using different data collection techniques. The data collection techniques used in the research are document review and unstructured interview. Since social media platforms such as Google Maps application, Sikayetvar and TripAdvisor allow to respond to the comments and complaints about Internet accommodation businesses, the relevant comments were included in the scope of the research during document review. As the study examines glamping businesses from a different perspective compared to previous research and presents originality in terms of the method used, it is anticipated that the results obtained will contribute to the literature.

\section{Literature Review}

\section{1. The Concept and Scope of Glamping}

Glamping, which has gained increasing popularity in recent years (Filipe et al., 2018), is a combination of the English words "glamorous" and "camping" and this concept is called luxury camping activity in general (Brooker and Joppe, 2013:1; Pereira, 2013; Ergüven, et al., 2015: 256, Vreš and Vreš, 2015: 42; Lee et al., 2019; Aksöz et al. 2020:188; Fernandes et al., 2021; Lu et al., 2021). Glamping, which is also defined as a type of outdoor recreational activity that offers tourists various activities in nature (Brochado and Pereira, 2017), begins with people moving away from their places of residence with the desire to be in touch with nature (Lyu, 2019); while doing this, it is a type of accommodation where luxury accommodation services as well as high-quality food and beverage services can be obtained, without giving up the luxury living and accommodation opportunities they are accustomed to (Boscoboinik and Bourquard, 2012) and which offers the opportunity to participate in recreational activities such as adventure and renewal in the context of sustainability (Birdir et al., 2015:172). Although glamping has just emerged as a concept in the literature, there is more than one accommodation type within the glamping type. These (Ergüven et al., 2015) are tents (Luxurious tents, bell tents, dome tents, teepee tents, safari tents), cabins (A-Frame cabins, log cabins, country homes, igloos, tree houses, etc.) and other (Towers, islands, houseboats, villas, restored historical places, etc.) accommodation types.

Looking at the starting point of glamping, it is striking that there are different examples. An example of which dates back to the Ottoman period shows "otag-i humayun" (the ottoman imperial tent complexes), which were designed to match the luxury of the sultan's palace and contained portable items the sultans carried with them on their way to expeditions as well as precious silk carpets and furniture; these complexes are expressed as luxury camping (Birdir et al., 2015:171; Olcay and Turhan, 2017:982). Another starting point for glamping is accepted as the early 20th century. In the early 1900s, American and European travelers would keep Persian carpets and comfortable beds in their safari tents during their safari trips in Africa and would take private cooks to prepare meals, guides, maids, and janitors with them, which shows the importance given to luxury. Outdoor accommodation experience in wildlife safaris at that time is a striking example of luxury accommodation (Boscoboinik and Bourquard, 2012; Brooker and Joppe, 2013:4; Birdir et al., 2015: 171; Olcay and Turhan, 2017:982). When we look at the first ones again, Goglamping.net has taken its place in the literature as the first glamping travel agency operating in the UK (Eremić, 2021:63).

Glamping tourism, which focuses on an unspoiled nature, is accepted as an environmentally friendly type of tourism. While businesses offering services with this view provide their services, they generally serve the products they have produced and natural and eco-friendly additive-free products as much as possible. Also, these types of businesses give importance to recycling (Sakacova, 2013:23-24). The target audience of glamping consists of individuals with high income and environmental awareness (Ergüven et al., 2015:256). Considering 


\section{F. K. Aylan - G. Çetin Gürkan 13/4 (2021) 3525-3543}

the characteristics of the individuals participating in glamping, which is a combination of camping and luxury holiday, it is seen that these are families and couples, wildlife lovers, peace-seeking individuals aged 50 and over, those who want to take a holiday by integrating nature and camping with the luxury and without thinking about the problem of camping equipment, prefer adventure, freedom and independence, prefer their families to be safe and commune with nature, want to get away from the stress of daily life, want a naturethemed holiday rather than the standard holiday concept, have high incomes, want to have direct contact with nature, and adopt a healthy and sustainable lifestyle (Yıldırım and Erkılıç, 2019:481). Sakacova (2013) states that there are push and pull motivations regarding the motivational factors of glamping tourists. According to Sakacova, the most significant push factor for glampers is attachment. Also, Sakacova remarks that family members or friends participating in glamping together strengthen their bonds with each other, and says that other push motivational factors are the desire of glampers to get to know new people and new environments in order to socialize with other glampers, the need of rest, relaxation and peace, and the desire to get away from daily routine life. In addition to the push factors, Sakacova also mentions the pull factors for glampers, including communing with nature, experiencing beautiful places, pursuing special interests (skiing, fishing, rock climbing, etc.), and the need for solitude/privacy, respectively.

\section{2. Complaint Management}

The Turkish Language Association (2021) defines the term "complaint" as "a word or statement expressing dissatisfaction, the act of complaining, discontent, and grievance". A complaint is also defined as "expressing that expectations are not met" (Alp, 2018). The complaint management process, which includes the business evaluating the complaints of the customers, making plans about them, managing and controlling these plans afterward, is considered as a strategy to know how to solve the consumer problems, to create the loyalty of the regular customers and to gain the potential customer (Kutluk and Arpaco, 2016:373; Özbay and Sarıca, 2020:861; Özgen, 2016:24; Bengül, 2019). Therefore, customer complaint management is defined as "analysis, planning, implementation and audit activities related to customer complaints" (Vos et al., 2008).

The methods by which businesses collect their complaints subject to complaint management are divided into two categories, based on relationship and technology. Relationship-based complaint collection methods include complaint boxes, employee and customer surveys while technology-based complaint collection methods are toll-free services, call centers, business website and social networks (Çeltek, 2013:173-175). When the use of the Internet was not so widespread, people used to convey their complaints to their addressees through traditional methods, but they have now started to convey their complaints in electronic media; thanks to the complaints called electronic complaints (E-complaints), they are able to convey them to many people, whether they are the addressee or not, in a short time, with less cost. Following and analyzing these e-complaints and informing the complaining customer about the solution process will increase customer satisfaction, thereby protecting the corporate image and increasing the demand (Alabay, 2012: Ergün and Kitapci:2018). On the other hand, customers who do not achieve satisfactory results may not only not buy services by running the process in the opposite way, but may also affect their environment with negative perceptions (Argan and Arıc1, 2019:341). Likewise, Wreden (2005) states that the unsatisfied customer who cannot be retained is one of the most important threats to the business. This is because satisfied customers share their satisfaction with an average of 4 to 5 people, but dissatisfied ones share their dissatisfaction with an average of 8 to 13 people. If dissatisfaction is shared through the Internet, this figure can reach even higher levels. On the Internet, bad news travels twice as fast as good news (Wreden, 2005). A business should consider the following points when responding to an e-complaint (Alrawadieh and Şehnaz Demirkol, 2015):

$>$ To thank the customer for their feedback and show that they are sorry for their dissatisfaction,

$>$ To show that the issues about which the customers' complaints are taken into consideration. The customer cannot always be right, but it is necessary to show that it is a valuable complaint without discussing whether true or false,

$>$ To promise that the customer will be satisfied if they stay at the business again and encourage their return.

Customer complaint and e-complaint are very common also in the tourism industry being a service-intensive sector and dealing with many tourists from different nationalities. Only the managers of the hotels could benefit from the information obtained by this traditional method used to measure customer satisfaction in the accommodation businesses, which are a notable pillar of the tourism industry, but travelers also have now 


\section{F. K. Aylan - G. Çetin Gürkan 13/4 (2021) 3525-3543}

accessed this information through various platforms such as Tripadvisor (Stringam and Jr, 2010). Thus, these comments or complaints, which are accessible to everyone and can be read by potential tourists, have brought tourism businesses to a different point in complaint management; some businesses have formed units or departments whose duties are only to follow up, deal with and solve comments, complaints, suggestions, etc. about their own businesses on social media, online holiday sites or only on platforms where complaints are reported.

The complaint is a concept that attracts the attention of researchers not only in the sector but also in academic terms, and there are various studies in the literature on this subject. For example, it is observed that there are studies that analyze the e-complaints of hotel customers in complaint forums or sites (Lee and Hu, 2004; Çulha et al. 2009; Aylan et al., 2016; Ünal et al., 2020), studies examining the effect of e-complaints on their purchasing decisions (Aymankuy, 2011) and also studies examining customer complaints about hotel businesses (Zheng et al. 2009; Sparks and Browning, 2010; Au, et al., 2014; Memarzadeh and Chang, 2015; Alrawadieh and Şehnaz Demirkol, 2015; Erdem and Yay, 2017; Kizılırmak et al. 2015; Sangpikul, 2019) and travel agencies (Kutluk and Arpac1, 2016; Tanrisever, 2018) on electronic review sites such as Tripadvisor. Since there is no study examining the electronic complaints of glamping customers in the literature, it is assumed that the research presents originality and will fill the gap in the literature.

\section{RESEARCH METHOD}

\section{1. Research Purpose and Sample Selection}

"Case study" was chosen as the qualitative research design of this study which aims to create a foresight about what kind of method is followed by glamping businesses, which have recently seen a widespread increase in accommodation tendency in Turkey, in e-complaint management and to develop various recommendations along with the results obtained. Within the scope of the case study, which can be expressed as examining one or more events or people in order to understand a subject, phenomenon or problem (Güler et al., 2015: 301), an in-depth research was carried out for the subject of this study by using different data collection techniques.

On the Google Maps platform, 16 glamping businesses, including the glamping business examined in this study, were found and the comments for all of them were analyzed. 11 of the 16 businesses examined did not respond to the comments, two of them gave very few (less than 10\%) responses, and almost all of the responses for both complaints were seen to be printed responses with the same sentences instead of a specific response to the complaint. For these reasons, the glamping business with sufficient number (30\%) and quality (specific response to the complaint) responses to shed light on the question to the research was taken as an example. 115 comments for the glamping business in the Google Maps application between November 2020 and April 2021 were detected within the scope of the research. These comments were uploaded to the word document and the document to be analyzed was prepared.

\section{2. Data Collection Method}

It has importance to use multiple data sources in qualitative research. Providing cross-validation with using two or more methods is a strong method, also referred to as triangulation (Sığrl, 2018: 171). Moreover, the case study design contributed to the validity of the research as it was suitable for data collection with more than one method. The data collection techniques used in the research are document review (Google maps/comments), participant observation and unstructured interview.

During participant observation, one of the techniques used while collecting data, the researcher takes an active part in the community and comes together with the relevant people (Baş and Akturan, 2017: 102). Therefore, one of the researchers stayed for 2 nights at the a glamping business subject to the research and witnessed the complaints encountered during document review and experienced some of the situations related to the complaint. Miles and Huberman (2019: 268) mentioned several features for the data collected by a researcher to be strong. Among these features, the researcher saw and transferred the data first hand, collected data in an informal setting, made direct observations of behaviors and activities, which supported a stronger interpretation of the data in the current study. The researcher also conducted an in-depth, unstructured, faceto-face interview with the owner/manager of the one glamping business on the management of complaints before check-out procedures. The interview took approximately one hour. Questions and responses focusing 
on the complaints and the process of responding to complaints were noted, recorded, and then transferred to electronic format.

\section{3. Analysis of Data}

The obtained data was analyzed by using the previously licensed MAXQDA@ 2018 package program. The MAXQDA® 2018 program allows to transfer qualitative data to electronic media, to analyze the transferred data, to theme, interpret and code the data easily. The comments for the business from the Google Maps application were copied to the word document and transferred to the MAXQDA@ 2018 program for content analysis (Tüfekci, 2014:775). Content analysis tries to "describe the data, reveal the truths that may be hidden in the data" (Yıldırım and Şimşek, 2016:242). Thus, the research aims to obtain a meaningful output by coding the data in the document within the framework of certain concepts/themes (Polat, 2020:293). The categories, themes and sub-themes were consisted of the topics mentioned in the comments (Strauss and Corbin, 1990) and divided into categories. The data analyzed in the research were evaluated under two categories: "ecomplaint" and "e-complaint management". There are "reception", "housekeeping", "price", "restaurant" and "other" themes under the e-complaint category. E-complaint management category includes the themes of "unanswered complaint", "unexplained complaint", "management policy", "trying to improve themselves", "stating that they are working on satisfying the demand", "correcting the mistake", "reinviting", "thanking for constructive feedback", "thanking for experience sharing", "saying they are sorry/apologizing" and "stating that the complaint is not true". A "Code-Co-creation" analysis was performed to examine the relationship between the "e-complaint" category and the "e-complaint management" category. For the study, each complaint and the responses to the complaint were checked manually and the responses to the complaints were determined and written with numbers on the arrows indicated on the relationship analysis maps. The numbers on the arrows were written to indicate the response which was given to the complaint. For example; a comment with 2 complaints about the theme of room cleaning was shared. No explanation was given to either of these two complaints. To indicate this situation, the number " 1 " was written on the arrow which showed that there was a relationship between the themes of "room cleaning" and "unexplained one". The number " 2 " was written on the arrow that showed the response to the second complaint about room cleaning, in which there were expressions stating that "they were sorry", "this situation was related to the management policy" and "they were trying to improve themselves", to indicate which of the complaints were responded.

The data were coded by two independent people with different subject-matter expertise in order to measure the reliability of the research. The study used the "reliability" formula for qualitative research by Miles and Huberman (1994:64), and the obtained rate was $86 \%$. The result that will be obtained by applying this formula to the data should be represented with a reliability percentage of at least 70\% (Miles and Huberman, 1994:65). Accordingly, the reliability of the coding was concluded to be at a sufficient level.

\section{FINDINGS}

The findings that emerged as a result of the analysis of the data from the research were reported with an approach from the general to the specific. Chart 1 shows the distribution of positive and negative comments about the glamping business by the guests.

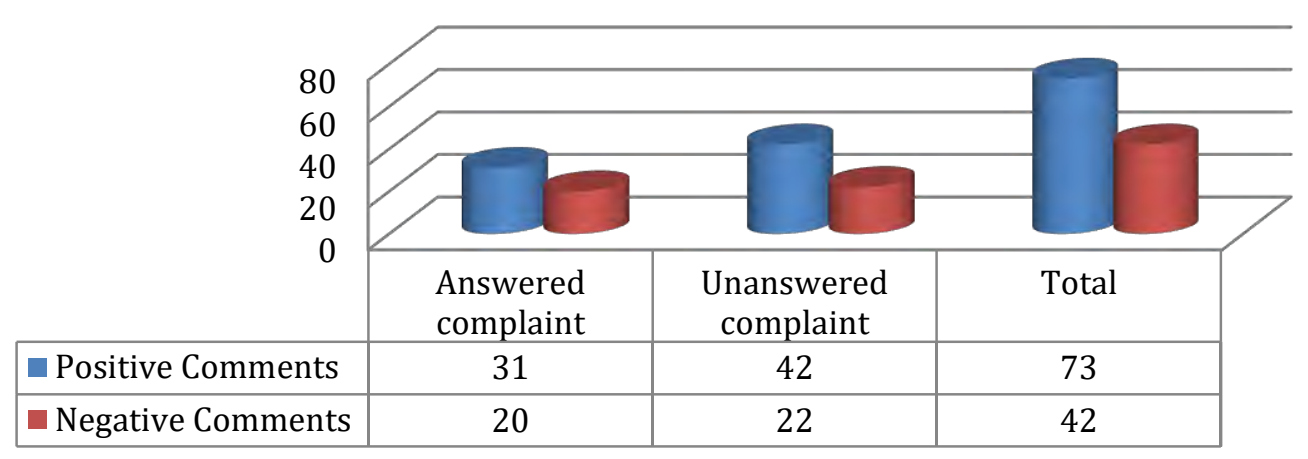

Chart 1. Distribution of Positive and Negative Comments by the Guests 


\section{F. K. Aylan - G. Çetin Gürkan 13/4 (2021) 3525-3543}

42 of the 115 comments by the guests were found to have negative content. When the responses to positive and negative comments were analyzed, more responses were determined to be given to positive comments than to negative comments.

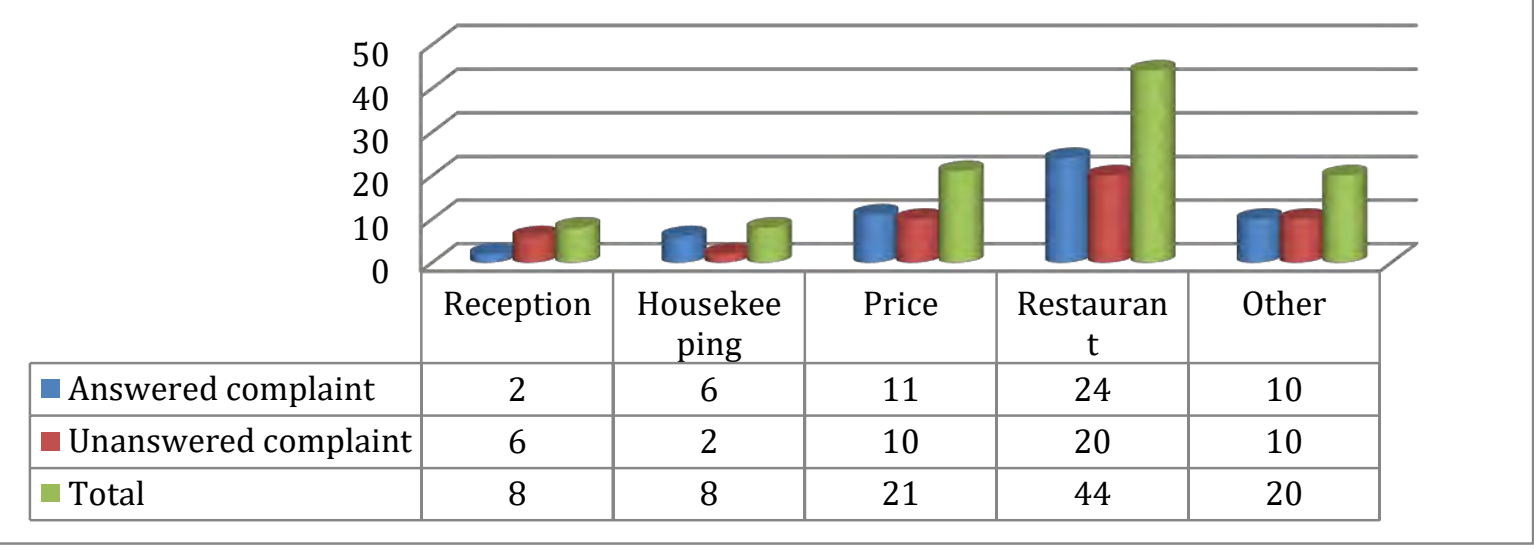

Chart 2. Distribution of the Responses by the Business According to the Subjects of the Complaints by the Guests

Chart 2 shows that the responses by the business to the complaints by the guests about the glamping business are divided according to their subjects. 101 complaints were made about reception, housekeeping, price, restaurant and other issues, and 53 of these complaints were responded but 48 were not. The restaurant of the business has been observed to be the most complained issue with 44 negative comments. On the other hand, reception and housekeeping departments have been observed to be among the least complained issues with 8 negative comments by the guests.

Table 1. Distribution of Responses to E-Complaints

\begin{tabular}{|lcccccc|}
\hline Themes of Response to E-Complaints & Reception & Housekeeping & Restaurant & Price & Other & Total \\
\hline Unanswered complaint & 6 & 2 & 20 & 10 & 10 & 48 \\
\hline Unexplained complaint & 1 & 2 & 11 & $*$ & $*$ & 14 \\
\hline Management policy & $*$ & 2 & 3 & 3 & 1 & 9 \\
\hline Trying to improve themselves & & 5 & 13 & 4 & 2 & 24 \\
\hline $\begin{array}{l}\text { Stating that they are working } \\
\text { satisfying the demand }\end{array}$ & $*$ & $*$ & 6 & $*$ & & \\
\hline Correcting the mistake & $*$ & $*$ & $*$ & 1 & 1 & 2 \\
\hline Reinviting & 1 & $*$ & 11 & 1 & 3 & 16 \\
\hline Thanking for constructive feedback & 1 & 1 & 7 & $*$ & 3 & 12 \\
\hline Thanking for Experience Sharing & 1 & $*$ & 6 & & 1 & 8 \\
\hline Saying They Are Sorry/apologizing & 1 & 3 & 8 & 5 & 2 & 19 \\
\hline Stating that the complaint is not true & $*$ & 2 & 1 & 2 & 7 & 12 \\
\hline
\end{tabular}

Table 1 shows the distribution of the responses by the business to e-complaints. It is noteworthy that the complaints not responded by the business have the highest rate. Based on the distribution of the responses by the business according to the themes, the responses stating that they were trying to improve themselves were often shared. Also the themes of "saying they are sorry" and "thanking for (constructive feedback and experience sharing)" were frequently used. The frequency of the complaints responded by the business with general statements without any explanation regarding the complaint subject is also striking. The number of responses stating that some complaints were not true was found to be high. However, the minimum number of responses is seen to be related to stating that the mistake was corrected. 


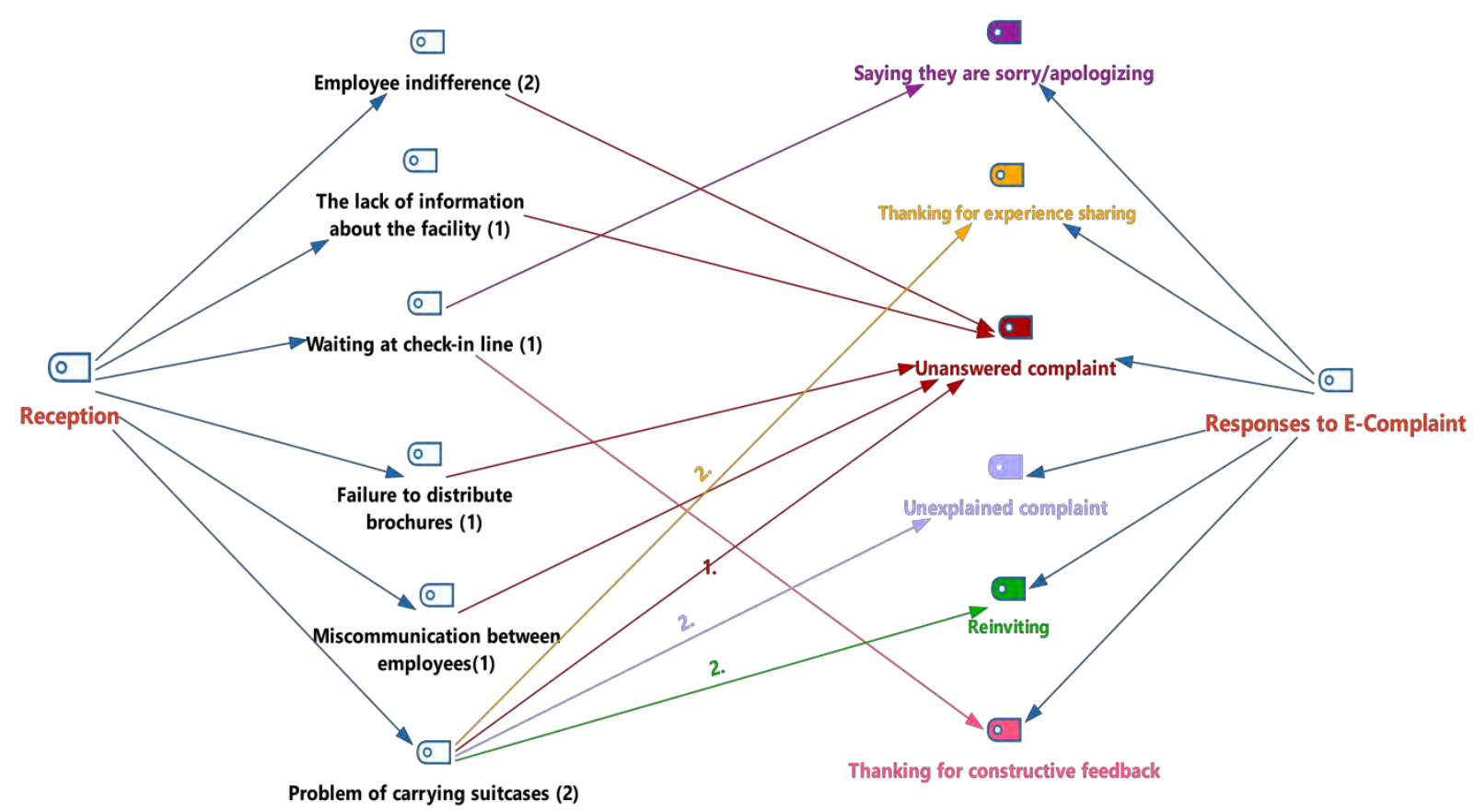

Figure 1. Paired Comparison of the Complaints of the Guests about the Reception with the Responses to the Complaints

Figure 1 shows the findings regarding the comparison of the complaints of the guests staying at the glamping business about the reception from the comments on the Google Maps website with the responses to these complaints. The visitors to the glamping business expressed their complaints about the reception such as employee indifference, the lack of information about the facility, waiting at check-in line, failure to distribute brochures, and miscommunication between employees. As can be seen in Figure 1, the glamping business did not respond to the complaints about employee indifference, the lack of information about the facility, miscommunication between employees, and failure to distribute brochures. Below is an example of the complaints by the guests and the response to the complaint.

-The guest stated her/his complaint about waiting at check-in line as "When we entered the facility, we had to wait in line for check-in". The business responded to this complaint with the statement "Hello, we apologize for keeping you wait for a while at check-in line. Thank you for your constructive comments, we wish you a good day" and apologized for the bad experience and thanked the guest for the constructive feedback.

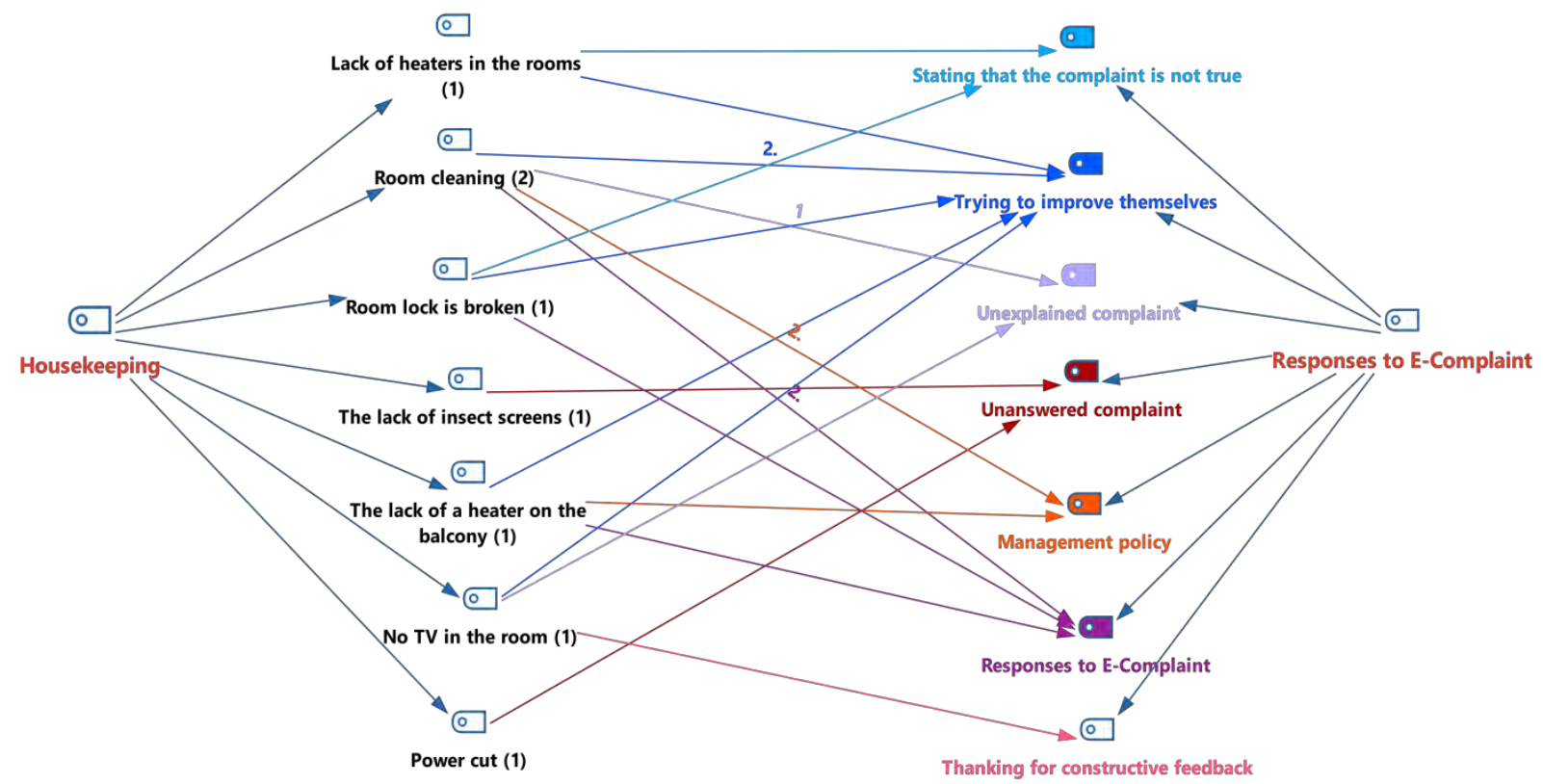

Figure 2. Paired Comparison of the Complaints of the Guests about Housekeeping with the Responses to the Complaint 


\section{F. K. Aylan - G. Çetin Gürkan 13/4 (2021) 3525-3543}

Figure 2 shows the result of the paired comparison of the complaints of the guests staying at the glamping business about housekeeping with the responses to these complaints. There are complaints about housekeeping such as the lack of heaters in the rooms, room cleaning, restroom cleaning, the lack of insect screens, the lack of a heater on the balcony, and power cut. The business did not respond to any of the complaints about restroom cleaning, the lack of insect screens, power cut and playground. The business did not give any explanation regarding a complaint about room cleaning but responded to the second complaint with the expressions stating that they were sorry for the bad experience, this situation was related to the management policy and they were trying to improve themselves. Below are statements regarding the complaints responded by the business.

-The guest made a complaint about the lack of a heater in the room, with the statement that "The heater in the rooms is insufficient". The business responded to this complaint with the statement "We recommend you to use the Convection heater apart from the air conditioner to heat the room. We are improving ourselves day by day in the light of your constructive feedback" and stated that the complaint was not true, there was another heating equipment in the room and they were trying to improve themselves day by day.

-The complaint about room cleaning with the statement "The floors are not cleaned in the daily room cleaning" was responded by the business as "Hello! First of all, we are sorry for your bad experiences. Our daily room cleaning is in the form of tidying the room when you do not specifically request. We are improving ourselves day by day to serve our guests better with the sincere criticism and feedback we receive from our guests" and the business stated that they were sorry, the situation subject to the complaint was related to the management policy and they were trying to improve themselves.

- A guest complained about the lack of a heater on the balcony by saying "There is no heater on the balcony". The business responded to this complaint with the statement "Hello! First of all, we are sorry for your bad experiences. We do not have a heater on the balcony of the tents. We are improving ourselves day by day to serve our guests better with the sincere criticism and feedback we receive from our guests" and stated that they were sorry and the situation subject to the complaint was related to the management policy and then mentioned that they were trying to improve themselves.

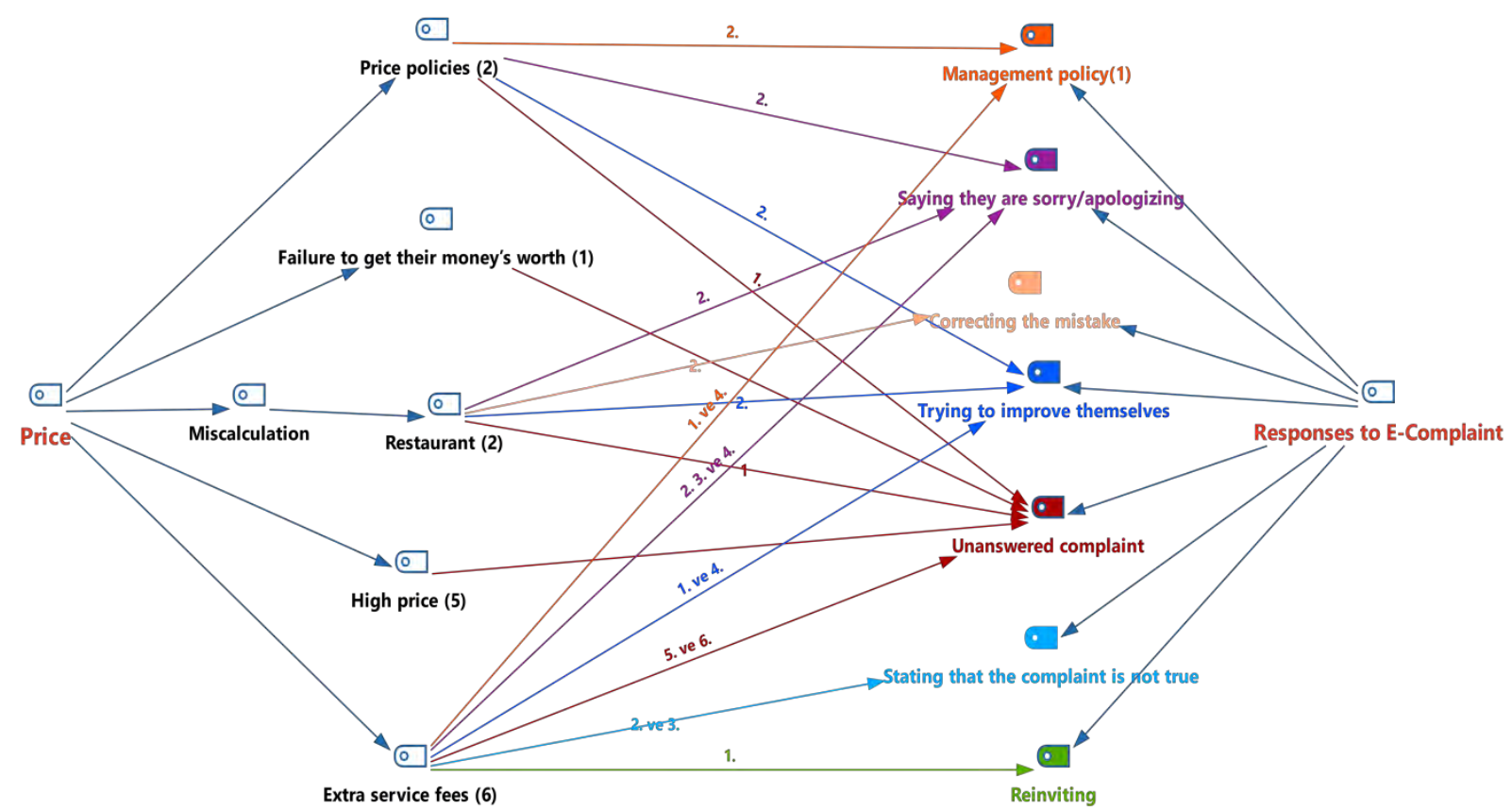

Figure 3. Paired Comparison of the Complaints of the Guests about Price with the Responses to the Complaint

Figure 3 shows the complaints of the guests staying at the glamping business about price and the responses to these complaints. The guests complained about the price such as price policies, failure to get their money's worth, miscalculation, high price, and extra service fees. Any response was not given to a complaint about price policies, one of the complaints about high price due to failure to get their money's worth, two complaints 
about extra services and a complaint about the miscalculation in the restaurant. Below are statements by the business, including responses to complaints.

-Regarding the miscalculation, the complaint was made through the comment "At a dinner, they put an extra 220 TRY on our tab. It would be wasted if we did not check it out." The business responded to this complaint with the statement "Hello! First of all, we are sorry for your bad experiences. At your dinner, wrong wine was entered into your system; this individual mistake was immediately corrected. We are improving ourselves day by day to serve our guests better with the sincere criticism and feedback we receive from our guests," and stated that they were sorry, the mistake was immediately corrected and they were trying to improve themselves.

-Regarding the extra service fees, a guest shared the post "So to speak, you have to pay an extra fee when you breathe in the facility. They said there was a guided nature tour, we joined it. It was subject to extra fee." The business responded to this complaint with the statement "Our pricing policy is based on your experience. All major Glamping Facilities around the world are managed on this basis. Rest assured that we will do our best to correct your bad experiences. We will be happy to see you at our facility again," and stated that their management policy was like that, they were trying to improve themselves and they reinvited the guest. Another guest's comment on this subject was as follows: "We used the adventure park. We learned that 60 TRY was taken from everyone during check-out. There was no indication at the entrance to show that it was a paid service. The treasure hunt was played. We learned that 40 TRY was taken during check-out." The business responded to this complaint with the statement "Hello! First of all, we are sorry for your bad experiences but we would like to correct a few misinformation. At the entrance of the Adventure Park, you sign for the acceptance of the relevant fee before the training and the fee is reflected in your room account. The relevant fee is written on the introductory paper in the Wayfinding game," and mentioned that they were sorry, but the complaint was not true.

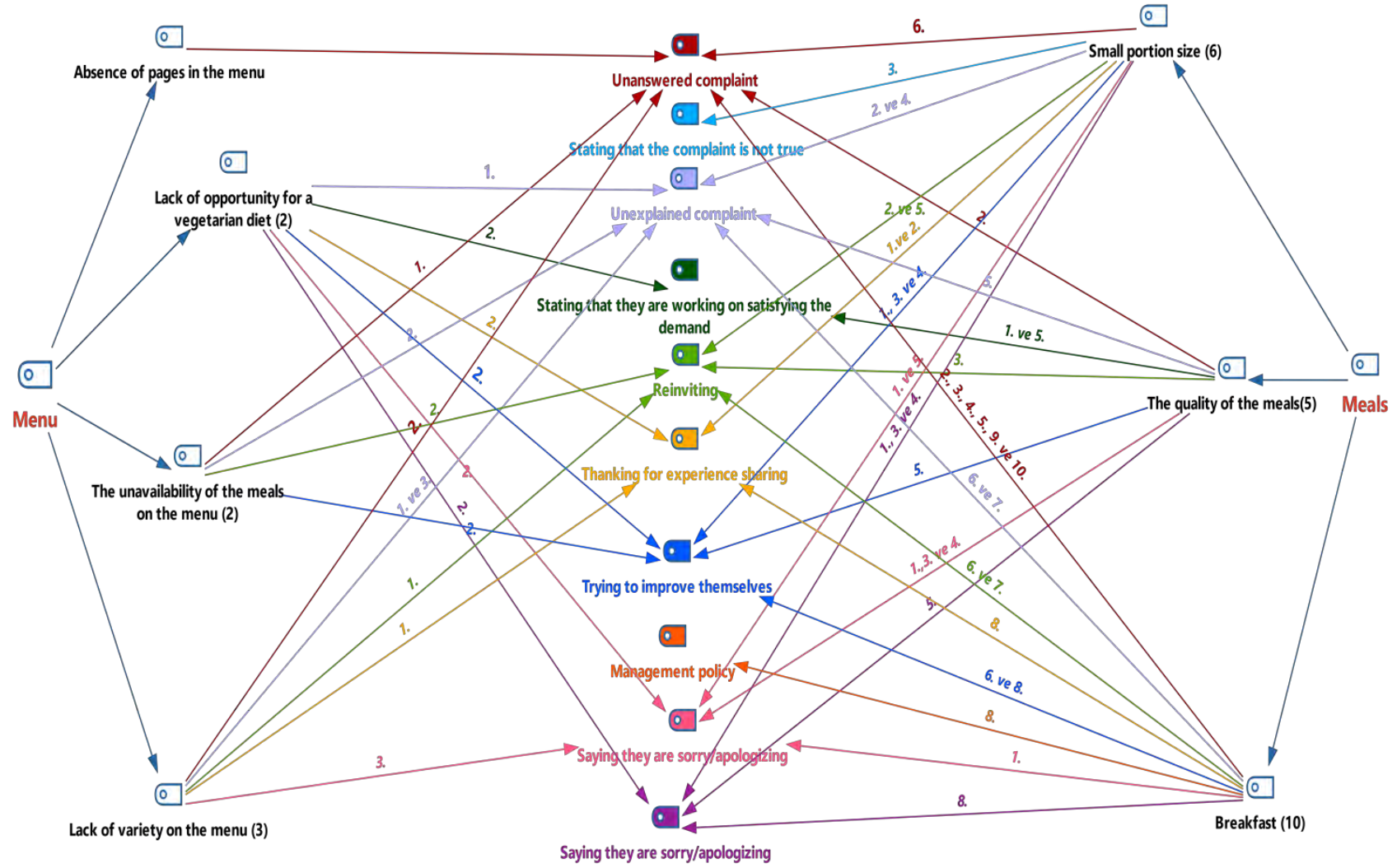

Figure 4. Paired Comparison of the Complaints of the Guests about the Menu and Meals in the Restaurant with the Responses to the Complaint

Figure 4 shows the complaints of the guests staying at the glamping business about the menu and meals in the restaurant and the responses to these complaints. The guests complained about the menu, such as the absence of pages in the menu, the unavailability of the meals on the menu, limited menu items, and the lack of opportunity for a vegetarian diet. Regarding the meals, they complained about the quality of the meals, the 
small portion size and the breakfast. Any response was not given to a complaint about the absence of pages in the menu, 6 complaints about the breakfast, and each one of the complaints about the unavailability of the meals on the menu, limited menu items, quality of the meals, and small portion size. The other complaint about the unavailability of the meals on the menu was responded, but no explanation was given and general statements such as trying to improve themselves and reinviting were used. Below are some posts where the complaints of the guests were responded and explanations were given.

-Regarding the lack of opportunity for a vegetarian diet, the guest made a complaint by saying " $I$ brought 4 sandwiches from outside with me. Luckily I brought them, I starved for 3 days! Since I am vegetarian and do not eat eggs, I asked the waiter if there was any alternative for breakfast and when s/he came back, s/he said that the chef could make an omelette with parsley for me.". The business responded to this complaint with the statement "Hello! Thank you very much for sharing your experiences at our facility with us. We are sorry for your bad experience at the restaurant. Our new menu will be used as of May 1 and we are getting the menu more delicious day by day. We are improving ourselves day by day to serve you better in our 9-month facility. Thank you for your good and constructive comments," and thanked for experience sharing, stated that they were sorry for the bad experience, they were working on satisfying the demand and they were trying to improve themselves.

-Regarding the unavailability of the meals on the menu, the guest made a complaint with the statement "It can be said that there are no any basic item. (e.g. feta cheese at the breakfast). Once again, I asked for coke zero, it was said to be out. So I rebelled against them on a small scale because there was nothing left we wanted". The business responded to this complaint with the statement "Rest assured that we will do our best to correct your bad experiences. We will be happy to see you at our facility again" without any explanation regarding the issue and generally stated that they would be trying to improve themselves and reinvited the guest.

- The guest complained that "The menu is not extensive" stating that there are limited menu items and the business responded to this complaint with the statement "Hello, thank you very much for sharing your experience. We were pleased to learn that we managed to meet your expectations during your stay. We were happy to hear about your experiences and memories. Our priority will always be the happiness of our guests! We hope to see you again at our facility as soon as possible. Wish you to be happy" without any explanation and thanked for experience sharing and reinvited the guest.

-Regarding the quality of the meals, a guest complained with the statement "It would be good if the meals were handled" and the business responded to this complaint with the statement "Thank you for your good comments. Also thank you for seeing the effort we put into as a newly-opened facility. You can be sure that we will make up for our shortcomings on your next visit" and thanked the guest for her/his constructive feedback and stated that they were trying to improve themselves. The guest's comment "Restaurant and meals should definitely be improved" was responded by the business with the statement "Thank you for your constructive comments. We would like to welcome you again" and they thanked the guest for her/his constructive feedback and reinvited her/him.

-Regarding the small portion size, a complaint was made with the statement "Portions are very small". The business responded to this complaint with the statement "Hello! Thank you very much for sharing your experiences at our facility with us. We are improving ourselves day by day to serve you better in our 9month facility. Thank you for your good and constructive comments," and thanked for experience sharing and constructive feedback and stated that they were trying to improve themselves. Another complaint about the small portion size was as follows: "We ordered the grill for two. The portion is so small that one person can barely get enough," and the business said that they were sorry for the bad experience $b u t$ the complaint was not true and they were trying to improve themselves day by day and stated; "Hello! First of all, we are sorry for your bad experiences but we would like to correct a few misinformation. The grill you sent in the photo is half of the portion. It is served in turn. We are improving ourselves day by day to serve our guests better with the sincere criticism and feedback we receive from our guests. We wish you a good day."

-Regarding the breakfast, a guest complained with the post "The breakfast included in the stay is too insufficient," and the business responded to this complaint with the statement "Rest assured that we 


\section{F. K. Aylan - G. Çetin Gürkan 13/4 (2021) 3525-3543}

will do our best to correct your bad experiences. We will be happy to see you at our facility again," and stated that they were trying to improve themselves for the bad experience and they reinvited the guest. Another complaint about the breakfast was as follows: "Breakfast is a bit poor." The business posted "Thank you very much for sharing your experience. We were happy to hear about your experiences and memories. We hope to see you again at our facility as soon as possible," and thanked for experience sharing, reinvited the guest but did not give any explanation regarding the issue.

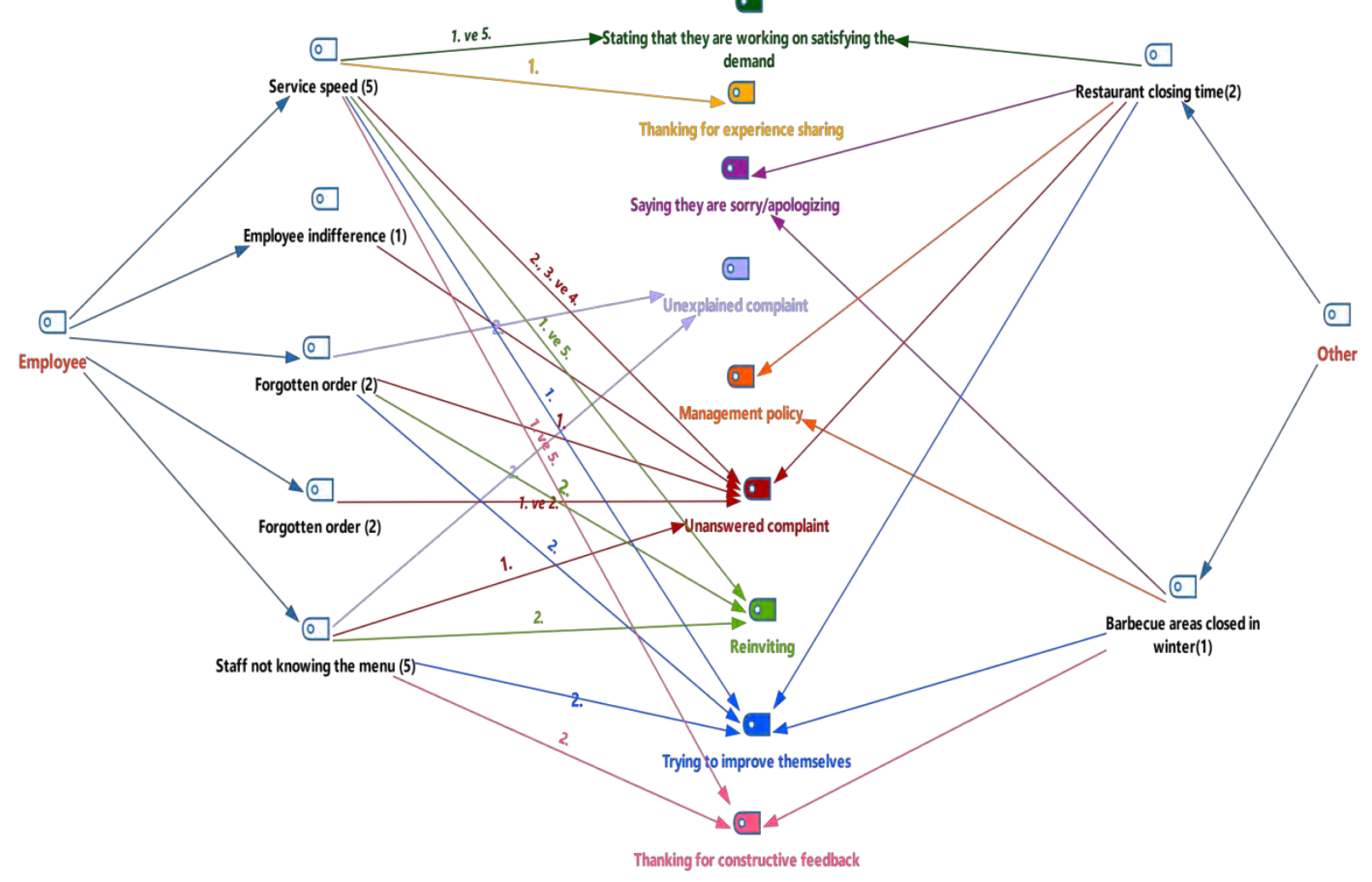

Figure 5. Paired Comparison of the Complaints of the Guests about the Employee and Other Issues in the Restaurant with the Responses to the Complaint

Figure 5 shows the complaints of the guests staying at the glamping business about the employee and other issues in the restaurant and the responses to these complaints. Two of the 5 complaints of the guests about the order speed in the restaurant were responded but the other three were not. One of the two complaints about the employee not being aware of the menu was not responded and the business thanked for constructive feedback without any explanation for the other complaint, stated that they were trying to improve themselves and reinvited the guest. The business responded in detail to the comments by the guests about the closing time of the restaurant and the barbecue areas being closed in winter. Below are the examples of the complaints by the guests and some of the responses to these complaints.

-Regarding the service speed, a guest's comment "Service is incredibly slow," was responded by the business with the statements including thanking for experience sharing, trying to improve themselves, stating that they were working on satisfying the demand and reinviting as follows; "Thank you very much for sharing your experiences at our facility with us. We are sorry for your bad experience at the restaurant. Our new menu will be used as of May 1 and we are getting the menu more delicious day by day. Our service team is being developed through training. We are improving ourselves day by day to serve you better in our facility. Thank you for your good and constructive comments."

-Two complaints were made regarding inexperienced employees. One of these complaints was not responded by the business but the other complaint "The restaurant has a team of the employees who try to be overly courteous but not good at it, inexperienced and not solution-oriented as much as possible. First, you have to ask for something several times," was responded by the business with the statement "Rest assured that we will do our best to correct your bad experiences. We will be happy to see you at our facility again," without any 
explanation as to the source of the complaint or solution recommendations and only stated "they were trying to improve themselves" and "reinvited the guest".

- A guest commented about the employee not being aware of the menu with the statement "The waiters do not have a good knowledge of the menu." The business responded to this comment with the statement "Thank you for your good and constructive comments. As a new facility, we quickly make up for our shortcomings. We will be happy to welcome you again," and did not give any explanation regarding the issue, thanked for constructive criticism, stated that they were trying to improve themselves and reinvited the guest.

A guest complaining about the closing time of the restaurant posted the comment "You cannot go out because of the quarantine. Therefore, you have to eat at the hotel. But the meal ends at 10:30 p.m. Then you are starved". The business responded to this post with the comment "Our facility has the same working hours since the day it was opened. All our guests are informed that the kitchen is closed at 10:30 p.m. Regarding the new demands, sausage sandwich will be made at Yin-yang Square very soon." The business responded to it with the statement "they were sorry, the situation was related to the management policy, they were working on satisfying the demand and they were trying to improve themselves.

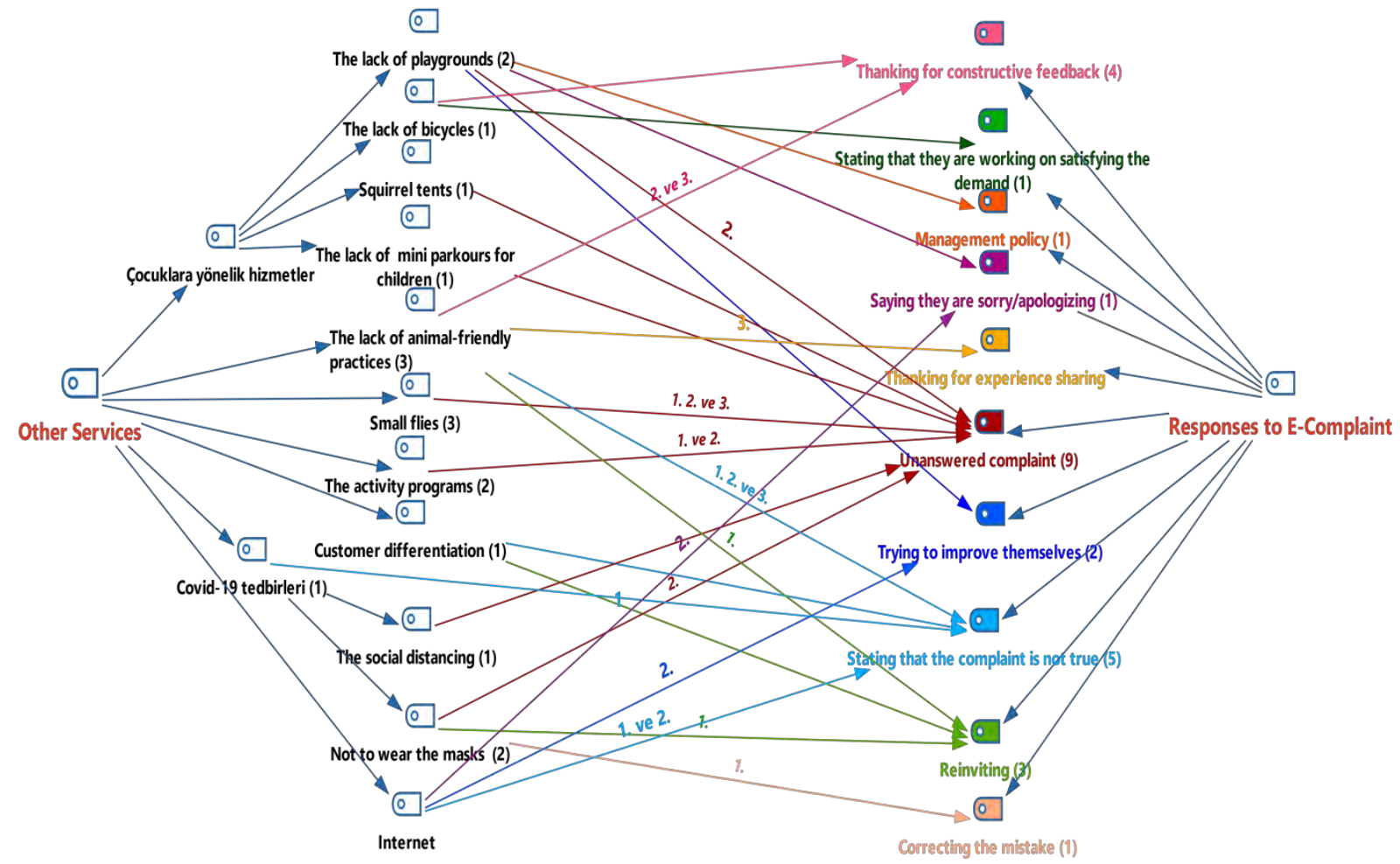

Figure 6. Paired Comparison of the Complaints of the Guests about Other Services with the Responses to the Complaint

Figure 6 shows the complaints of the guests staying at the glamping business about other services in the restaurant and the responses to these complaints. The guests shared the complaint about the insufficient squirrel tents for families with children, the lack of playgrounds, bicycles and mini parkours for children, the lack of animal-friendly practices, small flies, the problems in the activity programs, and failure to comply with Covid-19 precautions. From these posts, each one of the complaints about the insufficient squirrel tents for families with children, the lack of mini parkours, the problems in the activity programs, the social distancing rules and not to wear the masks was not responded. Below are some of the complaints responded by the business.

-Regarding the lack of bicycles for children, a visitor made a complaint with the statement "We said that we would ride a bike and we went to rent a bike. Unfortunately, there was neither a bike that was big enough to ride nor a bike that we could seat her/him in the back/side for my 6-year-old nephew," and the business responded to this complaint with the statement "Our bikes for the little ones will be used in the new season. Thank you for your constructive comments, we wish you a good day," and thanked for constructive criticism and stated they were working on satisfying the demand. 


\section{F. K. Aylan - G. Çetin Gürkan 13/4 (2021) 3525-3543}

-Regarding the lack of playgrounds for children, a guest made a complaint with the statement "There is no playground. There are children everywhere. But unfortunately there is no playground for children." The business stated that they were sorry, the situation was related to the management policy and they were trying to improve themselves, and responded to this complaint with the statement "Hello! First of all, we are sorry for your bad experiences. Children's playgrounds are not available as they are prohibited due to Covid rules. Children are aimed to get in touch with nature. We are improving ourselves day by day to serve our guests better with the sincere criticism and feedback we receive from our guests. We wish you a good day."

-Regarding the animal-friendly practices, a guest commented with the statement "Just when the meat started to cook, 8-9 dogs collected around us, the animals were starving and unluckily we did not have enough meat for all of them. When we got this answer, the dog was chasing after my 6-year-old nephew to take the meat from her/his hand and trying to get on the child. We shared some of the meat with the animals and went to Igneada and bought meat, etc. from the market for animals," and the business thanked the guest for constructive criticism, and stated that this complaint was not true as follows; "Our dogs are fed 2 times a day with both excess food in the restaurant and dry food. Before our newly-opened facility, all these dogs show an interest in this situation when they smell meat because of their habits routinized with over 400 dogs already in the center of Igneada. This situation is decreasing day by day as they are fed regularly. On the other hand, we provided financial support to the Igneada Municipality for the neutering, vaccination, and regular feeding of all stray dogs after their tagging. Very soon, all stray dogs in Igneada will continue their lives as healthier and fuller. Thank you for your constructive comments, we wish you a good day."

-Regarding customer differentiation, a guest made a complaint with the statement "There were ATVs at the entrance of the facility. We wanted to get information from the employee at the reception. It was said: "Unfortunately, we cannot let you use ATVs at the moment, we are waiting for permission from the gendarmerie for the route." By the way, there are celebrities/influencers inside. They were brought only for PR. A few hours later, we saw that these influencers posted a lot of stories with ATVs on their Instagram accounts. Well, are not they wait for permission for the route? What is a business logic where everything is free to influencers brought for $P R$ while rejecting the normal customer who pay for them!" The business responded to this complaint with the statement "Celebrities and influencers staying in our facility pay their fees and stay here. We would like to correct the misunderstanding on this matter. Their posts are based on their own free will. We do not have a sponsorship agreement with them. Our guided ATV tours started on April 05, 2021. Beforehand, our facility manager went on a hobby tour, I think you came across it. We will be happy to see you at our facility again," and stated that this complaint was not true and they reinvited the guest.

-Regarding not to wear a mask pursuant to Covid-19 precautions, there is a complaint such as "But unfortunately Covid precautions are zero. I took points off because of the kitchen staff and waiters not wearing masks". The business responded to this complaint with the statement "Thank you for your good comments. Our facility has the Safe Tourism Certificate and is regularly inspected. We think it was a momentary situation but rest assured that we will be much more careful about it. We would like to welcome you again," and stated that the mistake was corrected and they reinvited the guest.

\section{1. Interview}

One of the researchers stayed at the glamping business for 2 nights from 16 April (check-in) to 18 April (checkout), and witnessed the situations subject to the complaints in the content of the comments on the website, the attitudes and behaviors of the business managers and employees, and the situation of the problems caused by the physical facilities mentioned in the complaints. Moreover, an interview was conducted with the owner/manager of the business during this stay after the comment/complaint reviews within the scope of the document review of the research. Besides the general complaint issues obtained in the preliminary study, during the interview, it was tried to obtain information about how the comments containing complaints about the business were responded in the online environment. The manager was asked the question "What kind of approach and policies do they have on complaint management?". The business works in cooperation with a public relations agency in Istanbul and $80 \%$ of the complaints and comments are responded by the social media team of this agency. Some of the complaints are responded by the owner/manager of the business. $\mathrm{S} / \mathrm{he}$ emphasized that these complaints were those that $\mathrm{s} / \mathrm{he}$ witnessed, that $\mathrm{s} / \mathrm{he}$ was aware of, and that created a 


\section{F. K. Aylan - G. Çetin Gürkan 13/4 (2021) 3525-3543}

tension between the guest and the business management during the stay. The owner of the business confirmed that one of these complaints was a complaint written by a guest as 22 items, and the business responded with 22 items to each item.

Some responses to the complaints are stated to help the business to "improve themselves" as a standard. The owner/manager of the business was asked the question "How do these complaints guide them?". Based on the complaint "poor menu" about the food and beverage service of the business, s/he said that they had recently enriched their menu, an additional cooking unit had been built to add new foods to their menu and a pizza menu would be added. S/he stated that the comment "the vegetarian/vegan guests had difficulty in finding food on the menu", which was emphasized in two of the complaints, encouraged them to add vegan food to the menu. Also, s/he said that the presence of a lot of stray dogs was included in the complaints of some guests and that the entry of dogs could not be prevented because the area was a natural environment in the forest. However, s/he said that a protocol was signed with the municipality in which the business was located, the dogs were gradually neutered, the necessary vaccinations were made and all expenses were covered by the business. S/he emphasized that they planned to build a concrete wall at a certain height around the camp and to control them by putting a wire on it after these processes were completed. These examples give an idea that online complaints cause changes in the activities of the business in line with the demands of the guests.

\section{DISCUSSION AND CONCLUSION}

A complaint is a phenomenon that arises when customers provide negative feedback, they are not pleased with the goods and services of the business, or when they are dissatisfied or their expectations are not met. The Internet has a significant function in announcing this phenomenon to the relevant people and spreading it to the environment (Argan, 2014:52). The Internet is a channel that can be accessed easily at all hours of the day and night, with little or no cost to the individual. This feature leads to a great increase in customer complaints in the electronic environment and it is expected that this increase will continue in the future (Tripp and Gregoire, 2011). Since consumers' complaints are made in a public area, this necessitates good management of electronic complaints.

This study examined the e-complaints for a glamping business included in the scope of the research and the management of these e-complaints through the findings obtained by qualitative data collection methods. As a result of the study, the positive comments by the guests were responded more than the negative comments when the complaints and their responses were analyzed. It is important for e-complaint management that the business takes into account the negative comments and responds to them. Considering the negative complaints, businesses will not only avoid losing their customers by dealing with customer complaints and producing solutions, turning the complaint into satisfaction but also will be able to better meet customer expectations in their future services (Alabay, 2012). During the interview phase of the research, the owner/manager of the business stated that they received support from a professional public relations business while responding to guests' comments. It is likely that the majority of responses were generic rather than comment/complaint-specific because the professional public relations business was not a unit of the glamping business and was not associated with the area served.

Since the study was focused on e-complaints, the negative comments by the guests with 101 statements were subjected to content analysis. As a result of the analysis, it was observed to be divided into 5 themes: reception, housekeeping, price, restaurant and other issues. Responses to the complaint were also examined in detail and they included 11 different themes such as "unanswered complaint", "unexplained complaint", "management policy", "trying to improve themselves", "stating that they are working on satisfying the demand", "correcting the mistake", "reinviting", "thanking for constructive feedback", "thanking for experience sharing", "saying they are sorry/apologizing" and "stating that the complaint is not true".

Comparing the research results with the complaint management studies conducted for different accommodation businesses in the literature, it has been seen that there are some differences and similarities. Walker (2001) and Chu (2002) revealed in their studies that the most complained issue was the employees but this study identified that the most complaints were about the restaurant of the business similar to Alrawadieh and Şehnaz Demirkol's study (2015). Similarly, Tanrısevdi's study (2008) demonstrated that the third most frequently complained issue was related to the restaurant. As Aylan et al.'s study (2016) noted, the price policy 


\section{F. K. Aylan - G. Çetin Gürkan 13/4 (2021) 3525-3543}

was determined to be among the issues that received the most complaints in this study. Although Kırıc Tekeli and Tekeli's study (2020) found that there were practices for housekeeping among the issues that received the most complaints, the relevant study showed that housekeeping services were among the areas with the least complaints. As glamping businesses are in the form of accommodation in nature as a concept, this may cause the expectation of cleaning frequency to be low. The possible reason why fewer complaints are received from housekeeping services in traditional hotels in this business can be considered as low expectations. Looking at the responses by the business to the e-complaints, it is observed that the rate of not responding to complaints is high, similar to the study of Alrawadieh and Şehnaz Demirkol (2015). When the contents of the responded posts are examined, they are found to consist of statements including trying to improve oneself, thanking and expressing their sadness, in line with Zhang and Vásquez's study (2014). In the light of the findings, some recommendations were made to improve the e-complaint management process of glamping businesses;

$>$ Argan (2014) found that the companies responding the most to the complaint were at the top in the ranking of success. According to Andreassen (2019), corporate image has an important place in attracting new customers and regaining dissatisfied customers (Andreassen, 1999). Based on these two studies and the current study findings, an effective e-complaint management system should be established in order to increase the success performance of any glamping business and to create/prevent its corporate image from being damaged.

$>$ As a result of the study, the business responds more to positive comments while the rate of response to negative comments is low. The business should consider and respond to all comments, both positive and negative.

$>$ The way the business deals with the complaints of complaining customers is the determinant of the effectiveness of the business (Alabay, 2012). This study showed that some of the complaints were responded but no explanation was given regarding the complaint issues. The complaints expected to be explained were responded with the general expressions such as "we are sorry, we are trying to improve ourselves day by day, we look forward to seeing you again". Accordingly, it is important for the business to make detailed explanations about the customer's complaint in terms of increasing its service quality.

$>$ Zheng et al. (2009) stated that the business must find not only electronic reviews but also an effective way to deal with those reviews. When the business' responses to the complaints include expressions that are similar to the previous ones or standard phrases, it may lead to the guest's perception that $\mathrm{s} / \mathrm{he}$ is not cared about. Therefore, the unique response of the business to each complaint may play a key role in success.

$>$ It has been observed that the most frequently complained issues in the posts by the visitors are similar. From this point of view, businesses should constantly analyze all complaints within the scope of effective e-complaint management (Harrison-Walker and Erdem, 2000) and make the necessary arrangements in the business.

$>$ Effective e-complaint management enables an address or a promotional video of the business to be added to the responses to e-complaints, which will contribute to obtaining detailed information about the business and direct to the business' own site. As Armstrong and Hagel (1996) stated, this may generate additional interest by including links to the glamping business's service on complaint sites.

As a result, glamping businesses today need to meticulously review every complaint and carry out a successful e-complaint management process in order to meet consumer demands and reduce e-complaints on the public Internet. The limitation of this research is the use of only one platform (Google Maps) application. Ecomplaints in applications such as Tripadvisor and Twitter for glamping businesses can be analyzed for future studies. Furthermore, the natural role of the researcher in the evaluation of qualitative data and the analysis of a single business are obstacles to the generalization of the study results. 


\section{F. K. Aylan - G. Çetin Gürkan 13/4 (2021) 3525-3543 \\ REFERENCES}

Aksöz, E. O., Önem, B., \& Aydın, B. (2020). Kamp deneyimi yaşayan bireylerin glampinge ilişkin algılarının belirlenmesi. Gastroia: Journal of Gastronomy and Travel Research, 4(2), 185-196.

Alabay, M.N. (2012). Müşteri şikâyetleri yönetimi, Uluslararası Yönetim İktisat ve İşletme Dergisi, 8(16), 137-157.

Ali, F., \& Amin, M., (2014). The influence of physical environment on emotions, customer satisfaction and behavioural intentions in Chinese resort hotel industry. J. Global Bus. Adv. 7(3), 249-266.

Alp, H. (2018). Kamu sektöründe müşteri şikâyet yönetimi performansının müşteri memnuniyetine etkisi, Kent Akademisi, 11(3), 405-418.

Alrawadieh, Z. \& Şehnaz Demirkol, Ş. (2015). Konaklama işletmelerinde e-şikâyet yönetimi: İstanbul'daki beş yıldızlı oteller üzerinde bir çalışma, Nişantaşı Üniversitesi Sosyal Bilimler Dergisi, 3(1): 130-148.

Andreassen, T.W. (1999), What drives customer loyalty with complaint resolution?, Journal of Service Research, $1(4), 324-32$.

Argan, M.T. (2014). E-Şikâyetle ilgili tanımlayıcı bir çalışma: şikâyet forumu olarak bir web sitesinin sosyal ağ analizi, Internet Uygulamaları ve Yönetimi Dergisi, 5(1), 49-66.

Armstrong, A., \& Hagel, J. (1996). The real value of on-line communities. Harvard Business Review, 74(3), 134-141.

$\mathrm{Au}$, N., Buhalis, D., \& Law, R. (2014). Online complaining behavior in mainland China hotels:The perception of chinese and non-chinese customers. International Journal of Hospitality \& Tourism, 15, 248-274.

Aylan, S., Arpacı, Ö. \& Celiloğlu, F. K. (2016). Bir internet şikâyet forumundaki termal otellere yönelik şikâyetlerin incelenmesi. Çankırı Karatekin Üniversitesi Sosyal Bilimler Enstitüsü Dergisi, 7(1), 49-68.

Aymankuy Y. Ş. (2011). Yerli turistlerin internet ortamındaki şikayetlerinin satınalma kararlarına etkileri. Balıkesir Üniversitesi Sosyal Bilimler Enstitüsü Dergisi, 14(25), 218-238.

Baş, T. \& Akturan, U. (2017). Sosyal bilimlerde bilgisayar destekli nitel araştırma yöntemleri (3. Bask1), Ankara:Seçkin Yayıncılık,

Bengül, S. (2019). Müşteri şikayet yönetimi kalitesi belirleyicilerinin marka imajı ve marka bağlılığı üzerindeki etkisi, Galatasaray Üniversitesi İletişim Dergisi, 31, 252-276.

Birdir, K., Unur, K. \& Dalgıç A. (2015). Türkiye ve Dünya'da kamping ve yeni bir turistik ürün olarak 'glamping'. 1. Eurasia International Tourism Congress: Current Issues, Trends and Indicators (EITOC2015), 28-30 Mayıs 2015, Konya/Türkiye, 168177.

Boscoboinik, A. \& Bourquard, E. (2012). Glamping and rural imaginary. In H. Horakova, \& A. Boscoboinik (Eds.), From production to consumption: Transformation of rural communities. Zurich, Switzerland: Wien Lit Verlag Gmbh \& Co.

Brochado, A. \& Brochado, F. (2019). What makes a glamping experience great? Journal of Hospitality and Tourism Technology 10(1), 15-27.

Brochado, A. \& Pereira, C. (2017). Comfortable experiences in nature accommodation: perceived service quality in Glamping. Journal of Outdoor Recreation and Tourism, 17, 77-83.

Brochado, A., (2019). Nature-based experiences in tree houses: guests' online reviews. Tourism Review, 74(3), 310-326.

Brooker, E. \& Joppe, M. (2013). Trends in camping and outdoor hospitality. an international review, Journal of Outdoor Recreation and Tourism, 3-4, 1-6. https://doi.org/10.1016/j.jort.2013.04.005.

Çelik, N., Bahar, O. \& Tatar, S. (2017). Kırsal kalkınmada glamping turizmin rolü: Club Amazon Bördübet örneği, Uluslararası Sosyal Araştırmalar Dergisi, 10(51), 1282-1287.

Çeltek, E. (2013). Turizm işletmelerinde elektronik müşteri ilişkileri: (E-Miy). Ankara: Detay Yayıncllık. 
F. K. Aylan - G. Çetin Gürkan 13/4 (2021) 3525-3543

$\mathrm{Chu}$, R. (2002). Stated-importance versus derived-importance customer satisfaction measurement, Journal of Services Marketing, 16(4),285-301.

Çulha, O., Hacıoğlu, G. \& Kurt, G. (2009). Otel müşterilerinin e-şikâyetlerine yönelik bir içerik çözümlemesi. Seyahat ve Otel İsletmeciliği Dergisi, 6(4).

Davidow, M. (2000). The bottom line impact of organizational responses to customer comments. Journal of Hospitality and Tourism Research, 24, 473-490.

Düzgün, E. (2021). Pandemi sonrası yeni turist tercihi: glamping turizmi. ODÜ Sosyal Bilimler Araştırmaları Dergisi, 11(1), 145-158.

Erdem, Ö. \& Yay, Ö. (2017). Tripadvisor' daki müşteri şikayetlerinin değerlendirilmesi: Antalya örneği. Journal of Tourism and Gastronomy Studies, 5(4), 227-249.

Eremić, G. (2021). New trends in camping tourism - Glamping and family campsites Geoadria, 26 (1), 59-82.

Ergün, G. S. \& Kitapci, O. (2018). The impact of cultural dimensions on customer complaint behaviours: an exploratory study in Antalya/Manavgat tourism region, International Journal of Culture, Tourism and Hospitality Research, 12(1), 59-79.

Ergüven, M. H., Yılmaz, A. \& Kutlu, D. (2015). Turistik ürün çeşitlendirme bağlamında hibrit turizm: glamping örneği, International Journal Of Social Science, 41, 256257.

Fernandes, S., Ferreira, D., Alves, T., \& Sousa, B.M.B. (2021) Glamping and the Development of Sustainable Tourism: A Portuguese Case Study World Sustainability Series, 201-222.

Filipe, S., Santos, C.A. \& Barbosa, B., (2018). Tourists' motivations and obstacles for choosing glamping: an exploratory study. CBU Int. Conf. Proc. 6, 113-119.

Göktaş, S.,L., Gürel, Ç. \& Kızılırmak, İ. (2017). Özel ilgi turizmi olarak glamping turizminin mevcut durumu: bir örnek olay analizi araştırması, 4. Disiplinlerarası Turizm Araştırmaları Kongresi, Kuşadası, Aydın.

Grand View Research. (2021). Glamping Market Size, Share \& Trends Analysis Report By Accommodation Type (Cabins \& Pods, Tents, Yurts, Treehouses), By Age Group (18 - 32 Years, 33 - 50 Years), By Region, And Segment Forecasts, 2021 - 2028.

Güler, A, Halıcıoğlu, M.B. \& Taşğın, S. (2015). Sosyal Bilimlerde Nitel Araştırma, Ankara:Seçkin Yayıncılık, 2. Bask1.

Harrison-Walker, L.J. \& Erdem, S.A. (2000). Consumer complaining behavior: the case of the Internet", in Hartmann, J.J. and Mallette, P. (Eds), Proceedings of the Twenty-Ninth Annual Meeting of the Western Decision Sciences Institute, Maui, Hawaii, 18-21 April, WDSI, pp. 737-40.

Kırıcı Tekeli, E. \& Tekeli, M. (2021). Hizmet kalitesini arttırmaya yönelik e-şikâyetlerin değerlendirilmesi: sarıkamış otellerine ilişkin nitel bir araştırma. Atatürk Üniversitesi Sosyal Bilimler Enstitüsü Dergisi, 25(1) , 55-70.

Kızılırmak, İ., Alrawadieh, Z., \& Aghayeva, S. (2015). Doğu Karadeniz Bölgesindeki Otel Misafirlerinin Seyahat E-Yorumlarına Yönelik Bir İçerik Çözümlemesi. Gümüşhane Üniversitesi Sosyal Bilimler Elektronik Dergisi, 6,110-121.

Konak, S. \& Özhasar, Y. (2019). Türkiye'deki glamping işletmelerinin web site içeriklerinin analizi. Journal of Tourism and Gastronomy Studies, 7(2), 937-949.

Kutluk, A. \& Arpacı, Ö. (2016). E-wom bağlamında seyahat acentalarına yönelik e-şikâyetlerin gömülü teori ve içerik analizi ile incelenmesi, Balkesir Üniversitesi Sosyal Bilimler Enstitüsü Dergisi, 19(35): 367-386.

Lee, C.L. \& Hu, C. (2004). Analyzing hotel customers' e-complaints from an internet complaint forum. Journal of Travel \& Tourism Marketing, 17(2), 167-181.

Lee, W.,S., Lee, J..K., \& Moon, J., (2019). Influential attributes for the selection of luxury camping: a mixed-logit method. J. Hosp. Tour. Manage. 40, 88-93. 


\section{F. K. Aylan - G. Çetin Gürkan 13/4 (2021) 3525-3543}

Lu, J., Wang, X., Dai, Z., Chen, G., \& Feng, Y. (2021) Antecedents of customer WOM in glamping: The critical role of original ecology International Journal of Hospitality Management, 95, 102919.

Lyu, S.O., Kim, J.,W., Bae, S.,W. (2020). Family vacationers' willingness to pay for glamping travel sites: A family functioning segmentation, International Journal of Tourism Research, 22(2), 155-167.

Mattila, A. S., \& Mount, D. J. (2003). The impact of selected customer characteristics and response time on online comments satisfaction and return intent. International Journal of Hospitality Management, 22, $135-145$

Memarzadeh, F., \& Chang, H. J. (2015). Online consumer complaints about southeast asianluxury hotels. Journal of Hospitality Marketing \& Management, 24(1), 76-98.

Miles, M.B. \& Huberman, A.M. (2019). Nitel veri analizi, Çev Ed. Akbaba Altun, S. \& Ersoy, A., Ankara: Pegem Akademi, 3. Bask1.

Olcay, A. \& Turhan, U., (2017). Türkiye'de glamping hizmeti veren işletmelerin sahip ve yöneticilerinin "yeni turizm trendi glamping" ile ilgili görüşleri (Muğla ve Antalya Örneği). Gaziantep University Journal of Social Sciences, 16(4), 980-996.

Özbay, G. \& Sarıca, V. (2020). Yiyecek içecek işletmelerinde şikâyet yönetimi uygulamaları: Sakarya örneği, Türk Turizm Araştırmaları Dergisi, 4(2), 856-880.

Özgen, I. (2016). Otel işletmelerinde şikâyet yönetimi: Antalya ili örneğinde Rus turistlerin büyük ölçekli otellere yönelik e-şikâyetlerin değerlendirilmesi, [Yüksek Lisans Tezi.Dokuz Eylül Üniversitesi].

Pereira, C. M. M. (2013). Glamplingexp: Glamping experience, [Doctoral dissertation,. ISCTE Business School Instituto Universitario de Lisboa].

Polat, H. (2020). Halkla İlişkiler Alanındaki Doktora Tezlerinde Yeni Medya Olgusu: Nitel Bir Veri Analizi, Uluslararası Anadolu Sosyal Bilimler Dergisi, 4(4), 289-306.

Sakacova, K., L. (2013). Glamping- nature served on silver platter. [Master's Thesis, Aalborg University). https://projekter.aau.dk/projekter/files/76860450/Glamping.pdf

Sangpikul, A. (2019). The analysis of customers' e-complaints and service quality at spa servicesin Thailand. e-Review of Tourism Research, 6(6), 45-62.

Sığrı, Ü. (2018). Nitel araştırma yöntemleri, İstanbul:Beta Yayıncılık

Sparks, B. A., \& Browning, V. (2010). Complaining in Cyberspace: The Motives and Forms of Hotel Guests' Complaints Online. Journal of Hospitality Marketing \& Management 19(7), 797-818.

Strauss, A. \& Corbin, J., M. (1990). Basics of Qualitative Research: Grounded Theory Procedures and Techniques, Sage Publications, Inc.

Stringam, B. B. \& John G., Jr., (2010). An analysis of word-of-mouse ratings and guest comments of online hotel distribution sites, Journal of Hospitality Marketing and Management, 19, 773-796.

Tanrısevdi, A. (2008), Indirect customer voices to service failures: content analysis of e-complaints, A. Yuksel (Editör), Tourist satisfaction and complaining behavior: measurement and management issues in the tourism and hospitality industry, 247-261, Nova Science Publishers, Inc.

Tanrısever, C. (2018). Paket tur satın alan müşterilerin şikâyet analizi, Turizm Akademik Dergisi, 5 (1), 114-123.

The Turkish Language Association (2021). Şikayet, https://sozluk.gov.tr/

Tokay Argan, M. \& Arıcı, A. (2019). Sağlık iletişiminde e-şikayet: hastaların ve hasta yakınlarının sikayetvar.com paylaşımları üzerine bir araştırma. Akdeniz Üniversitesi İletişim Fakültesi Dergisi, (AKİL) (31), 339-355

Tripp, T. M. \& Gregoire, Y. (2011). When unhappy customers strike back on the internet, Sloan Management Review, 52(3), 37-44. 
F. K. Aylan - G. Çetin Gürkan 13/4 (2021) 3525-3543

Tüfekci, Ö. K. (2014). Spor pazarlamasında tüketici temelli marka değerini belirlemeye yönelik nitel bir araştırma: 9.Uluslararası ÖGER Antalya Maratonu (Runtalya) örneği. International Journal of Human Sciences, 11(2), 770-787.

Ünal, A., Çakır, G., Bayar, S. \& Çelen, O. (2020). Turistlerin konaklama işletmelerine yönelik şikâyetlerinin incelenmesi: Marmara bölgesi otellerine yönelik bir araştırma. Gümüşhane Üniversitesi Sosyal Bilimler Enstitüsü Elektronik Dergisi, 1(3), 744-755.

Union Lido (2012). Welcome to leading campings. Retrieved from //http://www. unionlido.com/sezioni.aspx?Id=9S>

Vos, J. F. J., Huitema, G. B. \& De Lange-Ros, E. (2008). How organisations can learn from complaints. The TQM Journal, 20 (1), 8-17.

Vreš, G., \& Vreš, D. T. (2015). Garden Village Bled glamping as an innovative revitalization of degraded landscape. AR. Arhitektur raziskave, 15(2), 40-47.

Vrtodušić Hrgović, A.,M. Cvelić Bonifačić, J. \& Milohnić, I. (2019). Dimensions of Service Quality in Glamping, Tourism in Southern and Eastern Europe, 5, 773-785.

Walker, L.J.H. (2001), E-Complaining: a content analysis of an internet complaint forum, Journal of Service Marketing, 15(5), 397-412.

Wreden, N. (2005). Profit brand: how to increase profitability, accountability \& sustainability of brand. Kogan Page

Yıldırım, A. ve Şimşek, H. (2016). Sosyal Bilimlerde Nitel Araştırma Yöntemleri, Seçkin Yayıncllık, Ankara.

Yıldırım, G. \& Erkılıç, E. (2019). An overview of glamping tourism within the context of the middle east tourism: the case of Turkey. Journal of Recreation and Tourism Research /JRTR, 6(4), 475-489.

Zhang, Y. \& Vásquez, C. (2014). Hotels' responses to online reviews: Managing consumer dissatisfaction. Discourse, Context \& Media, 6, 54-64.

Zheng, T., Youn, H. \& Kincaid, C. S. (2009). An analysis of customers' e-complaints for luxury resort properties. Journal of Hospitality Marketing \& Management, 18(7), 718- 729. 